\title{
THE ROLE OF CONSULTANCY FOR THE DEVELOPMENT OF ORGANIC FARMING IN BULGARIA
}

\author{
V. Agapieva*, V. Dirimanova, V. Koprivlenski
}

Department of Management and Marketing, Agricultural University, Plovdiv, Bulgaria

\begin{abstract}
Organic farming in Bulgaria is a new production method, which aims to provide quality and healthy food on the market. Farmers who produce organic products need adequate knowledge and specialized advice related to their production. The aim of this paper is to trace the importance of consultancy for the development of organic farming in Bulgaria. For this purpose we will examine, first, the role of consultancy specialized organizations to help producers of organic agricultural products through consultations on specific requirements, forms of financing and the necessary information; Second, the process of work between beneficiaries and consultants. One of the results of the study is that organic farmers are in constant need of specialized consulting services in terms of both compliance with the high requirements of this type of production and supply of quality organic products.
\end{abstract}

Key words: Bulgaria, consultancy, organic farming

\section{INTRODUCTION}

Organic farming as a way of thinking and practice is originated in the early years of the 20 th century with the application of various alternative methods of agricultural production. The method of organic farming is practiced in approximately 100 countries and agricultural areas under organic management are constantly increasing (10). Worldwide, there are a numerous definitions of organic farming. According to Lampkin, organic agriculture can be defined as a form of farming, which aims to a sustainable social, environmental and economic welfare by acting in three ways; it minimizes the use of external inputs, it maximizes the use of renewable sources and the exploitation of the agricultural ecosystem and, finally, it uses the market in order to counterbalance the external expenses (5). Bulgarian plan for development of organic farming is developed in accordance with the European plan for organic food and farming in 2004 and therefore adopted cited in its definition of "Codex Alimentarius" of the Food

\footnotetext{
*Correspondence to: Valentina Agapieva, Department of Management and Marketing, Agricultural University - Plovdiv, 12 Mendeleev Blvd, Plovdiv 4000, Bulgaria, Phone: +359 32654 435, Mob.: +359 877265 279, Email: vagapieva@au-plovdiv.bg, agapievavalentina@gmail.com
}

and Agriculture Organization (FAO) and the World Health Organization (WHO), (2).

Organic farming plays an important economic role in agriculture in Bulgaria. It goes back to provide market-oriented alternative for farmers who wish to meet the increased demand for high quality and environmentally friendly products. Organic farming covers a relatively small part of the utilized agricultural area in Bulgaria, but the sector is constantly evolving due to the ever-growing consumer demand.

As with any brand that certifies higher quality and origin of products, organic farming is related to strict compliance with established rules of production. In Bulgaria, organic farming is carried out in production units organic farms associated in several associations of orgnic agriculture. It is regulated on the basis of national certification programs with established structures for consultation, inspection, certification and accreditation. Agricultural produce can not be certified organic, before individual farms to go through a transitional period required, so called, conversion period. Any producer wishing to convert his farm organically should consult with a consultant on organic farming on whether this type of farming may be appropriate and proper alternative for holding. 
AGAPIEVA V., et al.

\section{MATERIALS AND METHODS}

Our preliminary survey among a number of organic producers, shows that there are many uncertainties organizational-economic and governance issues, and a large number of ambiguities involving regulation, legal basis, marketing and sales of organic products. All this necessitates the construction of specialized structures for consultancy as producers in the conversion and already certified as such. Undoubtedly, there are constant changes and requirements with regard to organic production. They entail and problems yet to be solved in practice. There is a need for common regulations, strategies and actions.

For this reason, the aim of our study is to identify the improvement of overall system quality and reliable information. This, emphasize the vital role of consultancy for the development of organic farming. In order to achieve this goal, we will analyze the activities of the responsible and partner institutions and organizations, which helps to reveal the nature, need, impact and role of consultancy for the development of organic farming in Bulgaria.

\section{RESULTS}

Despite the lack of long-term state policy for the development of Bulgarian organic farming, Bulgaria has a surprising position in the top ten countries with the largest growth areas with organic crops in recent years. According to a survey of international consultant A.T. Kearney, prepared according to the International Federation of Organic Agriculture Movements (IFOAM), in 20042006 certified organic area in Bulgaria increased from 500 to 12,284 hectares, or $2357 \%$ (11). In addition to the local market, European Union membership of Bulgaria offers additional opportunities for export of organic food and products for other states.

As known, counsulting is a professional communication and intervention, carried out by an institution in order to induce voluntary changes in customer behavior expected of public or collective utility. Customers seeking technical assistance usually when there is a specific problem that they can not cope alone. If counseling is applied participatory approach (joint participation of the client and the consultant in the search for solution to the problem) the benefit to the beneficiary is not only successful in solving the specific difficulty, but in the acquisition of new knowledge and skills which enable better dealing with emerging similar problem. Knowledge is farmers' best on-farm resource. The more they know, the better their decisions making will be. To utilize knowledge, however, they must have information. The most productive use of any organic farmers' time is spent in planning, figuring specific rules and requirements, figuring costs, and marketing. Thus, a little modern management applied to time-tested information from the consultancy will help make their organic farms a success (4).

The main objective of the consultancy on organic agriculture is to support the producers in the sector. As a rule, individual progress is useful not only for the beneficiary of consulting support, but in the extended scale for the settlement of the country as a whole and in the case of environmental benefits - and globally. This is the basis for public financial and non-financial support of consultancy at the national and even global level (FAO, World Bank, etc.). This support is not always unconditional. Consulting services are a tool to conduct a specific policy to achieve the objectives of the institution, which funds activities. Both groups are targets of consultants "operating" and common to those of the client. The purpose of the consultant is entirely covered with those of the client, and the economic, social and environmental effects of consultancy directly depend on the individual value orientation of the client - with any adjustment in the event of conflict with the objectives of customer requirements regulations relating to organic farming.

We believe that changes in government policy in one way or another often lead to changes in the objectives and tasks of the consultants. Undoubtedly, counseling services are complex hierarchical systems and set national targets to reach this consultant influenced in one way or another by the views of leaders from the upper levels of the hierarchy. In our view, the measurement of the effect of consultancy, particularly information and training is extremely complex task. This task is further complicated by the demand for social and environmental effects, not just the economic benefits of organic farming.

We found that depending on the number of clients counseling are classified as individual, group and mass. The first type is mainly applied in counseling, the second - in training, and the third - in information. Depending on the degree of participation of the consultant in the preparation of the decision of a problem counseling can be of three types. First, when the consultant identify the causes of the problem of his client, determine options to solve the problem and offers customers a 
turnkey solution, consultation called expert. Second, when the counselor and client work together on problem definition, detection of causes and identification of options for solving the problem, consultation is a process. Third, when the consultant educate customers how to make decisions and work independently client decision-making, consultation called trainers.

Undoubtedly, the conversion to organic farming brings novelty in humanitarian and technical sense. It also contributes to the accumulation of experience and eliminates concerns. Preparation for the transition goes through several stages. Their sequence depends on the type and economic situation of the farm. These are conversations with family, capacity of knowledge on organic farming experience of organic farming methods and the fourth stage - support consultant in organic farming. When the producer decides to make the first steps towards transition based on information gathered and their experience, he has to plan the transition with the help of a consultant on organic farming. Consultancy is essential due to the specifics of organic production requirements for organic farming, the desire to avoid loss of fuel due to a bad investment, and risk reduction in choice of inaccurate or incorrect alternative. For this purpose, there is a study duration of six months, which gives the farmer time to adapt its economy to the requirements.

The role of consultancy in organic farming has a huge and adequate support, it knows in detail the requirements for organic farming; may indicate structural changes to be carried out on the farm; provides information on the market offers, search, price of products which must be achieved; knows that the organization and the farm has tested technical solutions for them; advise the family about a possible reorientation of the economy and eliminate the risks; provides long written report which summarized the main points of the analysis results and solutions. For its part, the analysis of the farm meets the reason of issues with the pros and cons of organic production; deciding which branch of the holding to be untended or developed; what infrastructure adaptation or adaptation of buildings to be carried out; what is the need and capacity of the workforce in the future. The main reason for the changes is not only overproduction of subsidized crops, but increased sensitivity of European countries to protect the environment, biodiversity and animal welfare (7). In our opinion, these guidelines underline the need and importance of specialized consulting services for the In considering this question it is first necessary to make a distinction associated with specific activities. On the one hand, the consultant is required to assist its client and therefore their objectives regarding the development of the subject of the consultation are "common". On the other hand, the adviser seeks to achieve "operational objectives", which express the mission and interests of the organization for which he worked. The consultant with whom the farmers have contract, develops a plan for conversion, management plan tailored to the specifics of organic farming and specific plan to transform the holding. The latter contains highlights an analysis of soil condition; crop rotations; control of pests, diseases and weeds; methods to protect and preserve the environment and animal welfare. The recommendations of the consultant are also associated with the landscape elements and the buffer zone of the farm.

The preparation of a conversion plan is normally done by an adviser in conjunction with the farmer. The first stage is an assesstment of the motives behind the conversion, together with an analysis of the current situation on the farm. The second part involves the development of a target organic system and a plan for the transition between the current, conventional system and the organic endpoint (5). The correct decisions will make the whole conversion that much easier. The full conversion plan is quite a technical and, in some places, theoretical document which organic farmers is unable to complile properly on their own. In a such a dramatic change a professional advice is therefore necessary. The consultancy role is to prevent farmers from eventual negative consequnces as failure (1).

After passage of the transitional period, the producer may apply to the official control authority with which to conclude a contract for control of the economy and the issuing of a certificate and produced by him to be labeled as "organic". From what has been said here, we believe that the specialized consulting services on organic agriculture are vital for the implementation and development of organic agriculture in Bulgaria, covering both the new organic farmer and already existing ones.

According to the Program for Rural Development 2007-2013 and the Program for rural development 2014-2020, Measure 2 Consultancy services, farm management services and farm replacement and Sub- 
measure 2.1. - Help provide consulting services beneficiaries (suppliers) of consulting services are defined as advisory organizations measure (8). They are selected through calls for proposals. The selection procedure is governed by the procurement law and is open to both public and private organizations. To prove the existence of regularly trained personnel consulting organization must provide evidence of any major consultant and key consultants undergo specialized training or forms of training in the last seven years before the call for topics in the field of organic farming. Specialized training and qualification may include participation in seminars or courses, received a master's or doctorate, habilitation procedure.

One of the main strategies of the National Plan for Development of Organic Agriculture in Bulgaria in the period of 2006-2013 (NPDOA) is the functioning of the unified system of practice-oriented research, education, training and consultancy in the field of organic farming. According to the Plan, the operation of consultancy on organic agriculture is one of the strengths revealed in SWOT-analysis of organic farming in the country (7). At the same time, marked one of the main weaknesses lack of a system for consultations on organic farming at the national level, the reasons for which are insufficient and inadequate number of qualified consultants and the need for better coordination between the consultants in the field of organic farming. That is why the Plan provides and prepares strategies, objectives, tasks and activities that help to increase the number of consultants in organic farming in Bulgaria; professional development and conducting a course on organic farming consultants, which include practical training and end with the issuance of a certificate; creation and maintenance of a register of consultants on organic farming and publication via the website "Organic Farming"; development and implementation of the scheme for financial support for the use of advisory services for organic farming by farmers and others (7).

The implementation of these activities is assigned to the respective institutions listed below, which are responsible and partners. The Ministry of Agriculture and Food (MAF) is the competent authority for the implementation of policy in the field of organic production. MAF organizes the work of the Committee on organic farming and supervising control bodies and monitor the implementation of legislation in this area, and the introduction of changes in the European legislation (12). Participate and
AGAPIEVA $V$., et al. organize independently and in partnership with other organizations, dissemination of information/and promotion of organic production. Ministry of Agriculture and Food announces call for applications for the selection of institutions and organizations that can provide consultancy services under Ordinance №10 of 27.09.2011 on the conditions and procedures for granting financial assistance under the measure "Using of advisory services by farmers and forest owners' Programme for Rural Development for 2007-2013, Publ. SG No.79, October 11, 2011 " (7). One of the main problems facing these producers is underfunding of production. MAF as an intermediary redistribution of funds could support such producers not only informative plan, but by providing technical assistance in applying for various projects in order to attract more money into the production of organic products. Promotion of organic production could be carried out in cooperation with other state institutions such as the Ministry for Environmental Protection and Water, as organic production is actually a performing agricultural activity environmentally friendly (12);

The National Service for Plant Protection (NSPP) implements activities contributing to the development of organic production of crop production; The National Veterinary Service (NVS) implements activities that contribute to the development of organic production of livestock production; The National Service for Agricultural Extension (NAAS) MAF assists farmers in the implementation of effective organic farming through Disclosure of counseling, relevant information and applied research; The Ministry of Environment and Water (MEW) is the institution responsible for the overall protection of the environment in Bulgaria, including biodiversity conservation. Here it should be noted that organic farming is inherently aimed at maintaining and enhancing biodiversity and organic farming practices that consider biodiversity as a unifying term for all living forms and in its three aspects - genetic, species and variety of ecosystems; The Executive Agency for Selection and Reproduction in Animal Husbandry (EASRAB); The National Centre for Agrarian Sciences (NCAS) for MAF; Institute of Rose and Essential Oil Plants MAF; Executive Environment Agency to the Ministry; The Agricultural University in Plovdiv is one of the major universities in the field of agriculture in Bulgaria. From 1987 to agri-environment is operating center which is the first Bulgarian structure member of the International Federation of Organic Agriculture Movements 
AGAPIEVA $V$., et al.

(IFOAM), 1993. The main objective of the Centre is the training of personnel and support the development of organic farming in the country. The center has extensive experience as a coordinator and partner in many European projects and international programs.

The following three non-governmental organizations are essential to disseminate the philosophy of organic farming in Bulgaria, aimed at providing specialized in consulting services.

The Association for Organic Agriculture "Ecopharm" (1996) promotes organic farming among farmers and supports the implementation of this type of production. In 1996-1999, both the association and the Agriecological Centre of the Agricultural University in Plovdiv undertake the development of a PHARE project to create two demonstration organic farms and educational and scientific bases. In our study, the experts of the Association carry out consultations on all aspects of organic farming and crop protection in terms of organic production. They can be realized by e-mail, telephone or visits to the farm, previously specified conditions. Payment of these services is after coordination - by bank transfer or cash on the spot. Consultants develop specific technologies for organic production, development of plantspecific systems for organic crops; plan for transition of the farm; provide electronic copies of selected presentations on organic farming of the above, for seminars or training courses on organic farming, as well as participation of experts as lecturers in such forums (3); The Foundation for Organic Agriculture "Bioselena" (1997) is one of the main advisory bodies on organic farming in Bulgaria, and a member of IFOAM. The Foundation carries out training activities and support farmers in organic farming methods and crossing their farms to organic. In late 2003, a school farm "Solar Garden" was created as a demonstration center for schoolage children. So with the help of trained animators children enter the world of living nature. The creation of organic farm school is an initiative of the Foundation for Organic Agriculture "Bioselena" in partnership with the Agricultural University of Plovdiv, Sofia center for children and Royal Norwegian Society for Development - Norges Vel. Royal Norwegian Society for Development is an independent non-governmental organization with long experience in agriculture and farms open to visitors - children and adults (9); The Association "Agrolink" (1999) is established by a team of agronomists, botanists, doctors, scientists and experts. The association provides consulting services in the field of production, business plans for organic farming for manufacturers developing municipal plans and strategies for sustainable development of rural areas and the dissemination of information by issuing brochures, books, magazines and websites. The organization is a member of GENET - European network of NGOs working in the field of genetic engineering (3). For the promotion and development of organic agriculture in Bulgaria, we should mention the role of the following three organic producers' organizations.

The Association "Bioproduct BG" brings together eleven producers of organic production and non-governmental organizations working for the development of Bulgarian organic farming. The creation of the organization is inspired by the need for concerted efforts to develop the internal market in organic products, development of common marketing and marketing strategies, expanding consulting assistance to start organic farmers, as well as forming active consumer demand for quality organic products. In November 2004, with the support of the Swiss Agency for Cooperation and Development, the association opened the first stand for quality organic products in Bulgaria. Currently, the number of available organic products amounted to seventy-eight (3); The Cooperative "Bio Bulgaria - Oil" was founded by twenty-three farmers in 1999 within the project "Development of Sustainable Agriculture in Central Stara Planina" and has thirty-eight members. The building is open to anyone who wishes to focus on the production or processing of organic products. Since the beginning of 2001 "Bio Bulgaria - Oil" is an independent organization, and since the beginning of 2003 is a direct partner of SDC in implementing the marketing components of the project. At the end of 2004, members of the cooperative are certified 15,000 da areas; The Bulgarian Association Bio products (BAB) is an industry organization, uniting producers of organic products. The Association was established in late 2009 and it currently has more than eighty certified organic farmers, institutes and companies. Priority objectives of the $\mathrm{BAB}$ are - respect and protect the interests of organic producers in terms of financial support for rural development, helping to find markets for organic products, creating links between farmers and their foreign counterparts and organizations advising farmers legislative framework for the sector and inevitably, 
supporting the development of organic farming in Bulgaria (3).

\section{CONCLUSION}

Analyzing the nature and role of consultancy for the development of organic farming in Bulgaria, we believe that a good management, planning and consultation are the key to achieving effective organic production. First, the quality of organic products is directly dependent on the level of knowledge and information about the specifics and requirements of organic production. Second, the peculiarities of organic production require a vital in-depth knowledge on a number of administrative, regulative and practical conditions for organic producers. Third, it is our deep conviction that the support of specialized consulting services is crucial for the successful development of organic farming in Bulgaria.

\section{REFERENCES}

1. Blake, F., Organic farming and growing. The Crowood Press, United Kingdom, 49, 1990

2. Codex Alimentarius Commission, FAO/WHO, June 1999.

3. Foundations for Organic Farming, web sources.

4. Lampkin, N. H., Opportunities for Profit from Organic Farming. Paper presented to
AGAPIEVA $V$., et al. the RASE Conference "Organic Farming - Science into Practice”, 1997.

5. Lampkin, N. H., Organic Farming. Farming Press, United Kingdom, 529, 1990.

6. Macher, R., Making Your Small Farm Profitable. Storey Books, Canada, 218219.

7. National Plan for Development of Organic Agriculture in Bulgaria in the period of 2006-2013, 27, 71-108, 1999.

8. Programme for Rural Development 20072013, 76-96.

9. Project "Limitation of spread of food to misleading information on organic products", Bulgarian Association "Active Users" Foundation for Organic Agriculture "Bioselena", Article "Not fake organic food", 2007.

10. Willer, Helga and Lukas Kilcher, (Eds.), "The World of Organic Agriculture Statistics and Emerging Trends 2012." Research Institute of Organic Agriculture (FiBL), Frick, and International Federation of Organic Agriculture Movements (IFOAM), Bonn, 216-220, 2012.

11. http://www.atkearney.com/about-us/whowe-are.

12. http://www.mzh.government.bg/mzh/bg/. 